\title{
Science and the Glasshouse Industry
}

$\mathrm{I}^{\mathrm{N}}$ connexion with the Blackpool meeting of the British Association, Dr. W. F. Bewley delivered a public lecture on "Science and the Glasshouse Industry" at Blackpool South on September 11. Dr. Bewley prefaced his remarks by directing atten. tion to the importance of protected crops in any scheme of food production which might become necessary if Great Britain should ever be faced with another war, and argued that new land should be broken with the plough and brought into the high state of fertility which is essential for the successful cultivation of vegetables. He also stressed the value of such crops in the diet of the people.

To form an accurate opinion of the way in which science has helped the glasshouse industry to overcome the pests and diseases which once threatened its very existence, and the way in which it has directed progress, it is necessary to consider the position prior to 1914, when organized research became possible through the establishment of the Cheshunt Research Station.

Dr. Bewley described the serious damage once caused by the tomato moth caterpillar Polia oleracea ( $£ 40,000$ per annum in the Lea Valley alone), the white fly, Trialeurodes vaporariorum $(£ 25,000$ per annum), and the red spider mite, Tetranychus telarius. These pests were quickly controlled by measures devised at Cheshunt, and special note must be made of the importance of the chalcid parasite, Encarsia formosa, in controlling the white fly. Diseases such as 'damping off' and 'foot rot' eaused by Phytophthora spp., which destroyed thousands of plants in glasshouses, Verticillium wilt of the tomato (Verticillium albo-atrum), tomato leaf mould (Cladosporium fulvum) and many other diseases of glasshouse plants, which once extracted an enormous annual toll, were also brought under control.

Dr. Bewley directed attention to the importance of using a clean water supply in connexion with glasshouse plants and described the work done at Cheshunt on this problem.

The 'damping off' work was the means of discovering a soil drench (Cheshunt compound) which has since been applied on a large scale for the purpose of destroying certain fungi in the soil without injuring the growing plant. A large amount of work has also been done in connexion with virus diseases, which have attracted much attention during the past ten years. Virus diseases of the tomato were described in detail, and methods for identification, prevention and control were discussed. The importance of using virus-free seeds was emphasized. It was stated that scientific research has been pursued so effectively that it is now possible to control most of the serious pests and diseases of glasshouse plants.

Passing to the question of fungicides and insecticides, Dr. Bewley paid tribute to the work of many investigators in research institutes, universities and chemical firms, whose labours have provided the vegetable growers with new sprays of greater effectiveness. He mentioned the importance of the new sulphonated oil wetting agents and the work which is being done with regard to the use of insecticidal and fungicidal compounds carried in emulsified oils.
Soil sterilization has played an important part in glasshouse work, and the processes of chemical and heat sterilization were described. Sterilization by heat is the most effective and widely used, because it destroys a wide range of organisms, whereas chemical compounds are specific in action and it is difficult to obtain satisfactory penetration of the soil in practice. The latest method of steam sterilization, by means of the 'Hoddesdon' pipe system, was described.

Work at Cheshunt has included the breeding and selection of better varieties of tomatoes and lettuce, and of tomatoes resistant to Cladosporium fulvum. The tomato variety E.S.1 was distributed ten years ago and is widely used, for it yields a heavy crop of good quality fruit. The work on resistant varieties has been in progress for nine years, and it now seems that the goal is in sight, for good types have been grown this year which possess a high degree of resistance to leaf mould.

The lettuce Cheshunt Early Giant is one of the triumphs of the Station. It fills a long-felt want, for it can be grown in heated glasshouses from September until March and produces large well-hearted lettuce, even at Christmas. It has provided the English growers with a splendid opportunity for beating their foreign competitors, by providing fresh well-hearted lettuce during the autumn and winter.

In glasshouse work the physical condition of the soil is of great importance. Clean straw placed in the soil with the haulms vertical has proved beneficial, as has also the use of peat either mixed with the top soil or applied as a rooting medium to the surface of the soil during the summer.

Dr. Bewley also discussed the latest methods for warming the soil by circulating hot water in pipes buried two feet below the surface. This is a new development which will no doubt become general practice in the future. Soil warming increases the rate of root production, provides large clean root systems and heavy crops. It also increases the weight of crop picked during the first few months.

The workers at Cheshunt have also investigated the use of artificial light during the propagation stages. Useful results have been obtained with cueumbers but not with tomatoes. This application of light is being held up because a suitable source of light has yet to be found. This is a task for the engineers. Engineering science has helped the glass. house industry in the question of heating, and Dr. Bewley discussed the use of oil firing, automatic underfed stokers, gravity boilers and the steam-cum. water system.

Great importance is placed at Cheshunt upon the question of quality in vegetables of all kinds, and recently the question of tomato marketing packages was investigated. It was found that high tempera. tures cause the fruit to be disfigured by a yellow mottle known as 'high temperature mottle' and that bad ventilation causes softness. A new wooden box and perforated lining paper have been devised which allows the fruit to be adequately ventilated and kept in a cooler condition. It has been tested thoroughly during the past season and has given excellent results. 